Јован Савин

самостални истраживач yovansavin@,gmail.com
316.75

https://doi.org/10.18485/ai_lik.2019.5.8.3

Оригинални научни рад

\title{
НОВИ РОМАНТИЗАМ КАО ДЕО БРИТАНСКОГ ДРУШТВА У ПРВИМ ГОДИНАМА ДЕВЕТЕ ДЕЦЕНИЈЕ ДВАДЕСЕТОГ ВЕКА И ЈУГОСЛОВЕНСКИ МУЗИЧКИ НОВИ ТАЛАС КАО ОДЈЕК ЗАПАДНЕ ПОПУЛАРНЕ КУЛТУРЕ НА БАЛКАНУ
}

Рад представља покушај социолошке, економске, политичке и супкултурне анализе европског и југословенског друштва девете деценије двадесетог века кроз призму поп музике која је у тој деценији добила назив Нови романтизам. Кроз историјско подсећање на друштвена дешавања у Европи и Југославији анализира се супкултурни феномен оличен у музичком споту као иновацији западне цивилизације и њених вредности које су се на разне начине преливале у Југославију мењајући политичке и уметничке парадигме југословенског друштва.

Кључне речи: Нови романтизам, музички спот, југословенски Нови талас.

Осамдесете године двадесетог века су у европском и америчком културном наслеђу остале упамћене као веома интензивне у погледу смењивања историјских догађаја који су утицали на социјални, политички, економски и уметнички живот та два континента, па и целог света. У овом есеју биће речи пре свега о Новом романтизму, модно-музичком изразу младе британске генерације која је своје идеје представљала у виду: екстравагантног облачења, андрогиније, претераног шминкања и мушкараца и жена као и специфичног музичког израза који је настао као својеврсни одговор 
на анархоидност панка, а којег су карактерисали поп мелодије са наглашеном употребом синтисајзера, ритам машина, секвенцера и сличних електронских уређаја. У комбинацији са иновативним продукцијским захватима и једном новином која се звала музички спот, који је свему давао додатни визуелни гламур, Нови романтизам је изнедрио изванредне поп групе и појединце чији су музички радови заслужили значајно место у светској културној заоставштини.

Прву половину осамдесетих година у Британији и Америци обележиле су владавине Маргарет Тачер и Роналда Регана. Обоје су се као конзервативци залагали за повратак на традиционалне вредности као и за јачање економије и војске. Не треба сметнути са ума да је то период последње деценије хладног рата између два велика светска блока и две идеологије - западне демократије и совјетског комунизма, које су се сукобљавале у свим сферама, па и на пољу културе. Социјалистичка Федеративна Република Југославија (СФРЈ) припадала је блоку несврстаних земаља, углавном из Африке и Азије, и имала је самоуправно социјалистичко уређење. Интересантно је како су специфичне политичке околности из претходних деценија социјалистичку Југославију довеле у позицију да управо она, без обзира на своје комунистичко наслеђе, на сред Балкана, окружена државама источног блока, буде терен на који ће се прелити прогресивне идеје америчког Новог таласа и британског Новог романтизма. О овоме ће више речи бити у другом делу овог есеја.

Значајни историјски догађај на англо-америчком подручју у првој половини осамдесетих је свакако Фокландски рат (1982) између Аргентине и Уједињеног Краљевства, који се завршава победом Уједињеног Краљевства и враћањем Фокланда под протекторат Британије. Са друге стране Атлантика, Реган промовише Рай звезgа, одбрамбени војни програм који подразумева стационирање сателита у орбити који би могли уништити непријатељске совјетске и севернокорејске балистичке нуклеарне ракете. Вероватно је мало коме тада падало на памет да ће политичка и војна напетост између два блока у другој половини декаде кулминирати једним од можда најзначајнијих догађаја у модерној 
историји цивилизације, падом Берлинског зида. Још веће изненађење је тек следило: ускоро се распала комунистичка империја - Совјетски Савез. Ти догађаји пред крај осамдесетих и почетком деведесетих година двадесетог века условиће сасвим нове политичко-економске односе, пре свега у Европи која је доживљавала трансформацију. Већ поменута социјалистичка Југославија, у том историјском моменту политички потпуно обезглављена, десет година после смрти Јосипа Броза Тита, биће гурнута у кошмар погубног грађанског рата.

Вратимо се популарној култури и првим годинама девете деценије прошлог века у Британији. Крајем седамдесетих, панк еуфорија је сплашњавала и многе групе су покушавале да бунтовну реторику панк музике, која је водила у деструкцију, дрогу и алкохол, преточе у нови, креативнији и уметнички вреднији музички израз. Слично су размишљали и многи поклоници панк-рока који су добровољно мењали свој музички укус и полако прелазили на мање агресивни пост-панк, синт поп, Нови романтизам, нови поп, електро поп а касније инди, урбани поп, брит поп итд. Сви горе набројани музички правци; могу се сврстати у покрет који се једноставно звао Нови талас (New Wave). Тај покрет који, као што је већ поменуто, није био само музички него је подразумевао и специфичан начин облачења и размишљања, у себи је носио оптимизам младе генерације окренуте ка будућности. Међутим, испуњење снова те генерације није било окренуто остварењу утопијских нада претходне деценије делимично описаних у делима неких англо-америчких писаца научне фантастике попут Артура Кларка (Arthur C. Clarke) и Исака Асимова (Исаа́к Юgович Озимов).

Такве наде и снови би се морали остваривати кроз друштвени и политички ангажман, а не само пуким текстуалним и музичким описом хедонизма који је појавом музичке телевизије (MTV) постао још очигледнији. Чини се да се ту могу повући паралеле између генерације која се одушевљено укључила у хипи покрет крајем шездесетих година двадесетог века, критикујући америчко ангажовање у вијетнамском рату, и генерације Новог романтизма, која нема 
шта да критикује и окреће се будућности, а обе на крају завршавају у декаденцији и хедонизму не предузимајући ништа како би се њихове идеје и циљеви остварили.

Осамдесете су почеле пре осамдесетих. Увод у маскараду десио се током седамдесетих, када се истиче једна изванредна уметничка личност, Дејвид Боуви (David Bowie, 1947-2016). Бројним променама свог имиџа, интензивним шминкањем, увођењем свог алтер ега, Зигија Стардаста (Ziggy Stardust), који пева о својим пустоловинама, као и успешним глумачким и музичким ангажманима, овај мултиинструменталиста, глумац и певач сасвим случајно ће постати узор бројним бендовима окупљеним око лондонског клуба Блиц (Blitz). Из мноштва музички веома сличних састава, својим идејама и квалитетом ће се истаћи: Visage, Duran Duran, Adam and the Ants, Spandau Ballet, Soft Cell, Simple Minds, The Human League, Thomson Twins, Depeche Mode и Ultravox. Ca друге стране Атлантског океана, по сличном моделу преливања утицаја из седамдесетих у осамдесете, настаће новоталасне групе и извођачи попут: Talking Heads, Patti Smith, Blondie, The Ramones и Television са редовним наступима у њујоршком клубу Ци Би Џи Би (CBGB).

Из наведеног списка поп група, који се још знатно може проширити, можда би ипак требало издвојити два. То су: Визаж (Visage) и Алтравокс (Ultravox). Први је пример храброг и веома успешног комбиновања моде, шминке, андрогиније, гламура и музике, док је потоњи типичан пример преливања седамесетих у осамдесете, где се добија нови квалитет.

Идејни творац групе Алтравокс био је Џон Фокс (John Foxx), право име Денис Ли (Dennis Leigh), уметник, текстописац, композитор, визионар и певач, који је на прва три албума групе потписао скоро све песме. Како је и са̂м рекао у интервјуу датом професору Антонију Елиоту (Anthony Elliott), директору „Наwке“ истраживачког центра са јужноаустралијског универзитета, Фокс је сматрао- да, у складу са Гешталт психолошком школом, спој појединаца неке групе даје један нови ентитет са јединственим квалитетом који се не налази у појединачним члановима групе. На трагу Фоксових мисли је и познати рок новинар Петар Луковић, 
који је у часопису Рок 82, у броју 32 од 17. 11. 1982 године, у уводу приче о групи, хвалећи при том њихов тада најно-

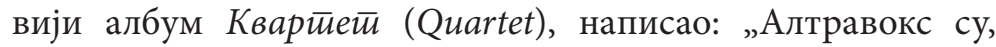
испада, много значајнија целина од збира њихових делова.“ (Луковић 82: 4). У веома информативном тексту Луковић је југословенској публици представио групу од својих почетака од средине седамдесетих до 1982. године. Прва два албума су типични представници пост-панка са прилично нејасним експериментима који су укључивали за тај правац неспојиве инструменте као што су виола и саксофон међутим, како Луковић лепо примећује, трећи, Systems of Romance je:

даљи рођак Виене, али уморни Беч то још увек не зна. Равне електронске површине, вокали као глечери, свет на ивици дехуманизације и Алтравокс као посматрачи хорор филма који нема хепи-енд. На жалост, публика не реагује. Пост-панк бум претворио се у Нови талас, у лагану одисеју поп звука који не пристаје на радикалну промену какву Алтравокс нуде (Луковић 82: 6).

Џон Фокс напушта бенд и посвећује се делимично успешној соло каријери, а Денис Ли ће пар година касније свој алтер его - Џона Фокса суспендовати на извесно време. Тек ће га 1997. године поново покренути са новим уметничким пројектима и дуетима које је имао са Луисом Гордоном (Louis Gordon) и Харолдом Бадом (Harold Budd). Колико је био у праву када је причао о концепту бенда којег је створио и његовом јединственом квалитету који, по свему судећи, не носе појединци него сама група, потврдиће невероватан успех албума Vienna са истоименом песмом као хит синглом, која је настала када се потпуно истом саставу након његовог одласка прикључио ветеран Миџ Jур (Midge Ure). Пре него што се поздравимо са Џоном Фоксом, или боље речено, оним што тај лик представља за поп музику и представимо другу, много познатију фазу у раду групе Алтравокс под диригентском палицом Миџа Јура, треба цитирати круцијалне моменте из Фоксове песме My Sex који гласе: „My Sex is a spark of electro flesh, a neon outline on a high-rise overspill... 
skyscraper shadows on a car-crash overpass... It wears no future faces, owns just random gender." ${ }^{1}$

Очигледно је Фокс инспирацију за своје текстове за групу Алтравокс, које је писао од средине до краја седамдесетих, налазио у тада веома свежој научнофантастичној прози британског писца Џејмса Грејема Баларда (James Graham Ballard, 1930-2009). Из претходно наведеног цитата песме My Sex могу се назрети теме и мотиви романа Cygap (Crash, 1973) и Сйамбени блок (High-Rise, 1975). То су, како добар познавалац Балардовог опуса; Новица Петровић у свом есеју о мотиву ентропије у делу Џ. Г. Баларда каже: „напуштена места изложена пропадању: празни хотели, опустела летовалишта, испражњени базени, напуштена градилишта, зарђале лансирне платформе, места која су некада била средишта људске активности а сада су напуштена." (Петровић 2005: 372). То су детаљи које Луковић препознаје као „равне електронске површине, вокале као глечере и свет који је на ивици потпуне дехуманизације“. (Луковић 82: 6)

У јесен 1980. године, Алтравокс у Келну са новим, искусним певачем и гитаристом Миџом Јуром снимају албум Vienna у студију Конија Планка (Conny Plank) који је продуцентску популарност стекао снимајући и продуцирајући немачки електро-бенд Крафтверк (Kraftwerk). Албум након појављивања пада у лагани зимски сан, међутим, сингл „Vienna” се убрзано пење ка врху свих топ листа.

Првога августа 1981. године, МТВ је званично почео са емитовањем. То је био историјски тренутак јер се почела развијати читава индустрија музичког спота, која је приказивала једну сасвим нову слику новог романтизма као меланхоличног и хладног правца. Аустралијски редитељ Расел Малкахи (Russel Mulcahy) који је претходно режирао филм Горшйак (Highlander, 1986) и спот за дует Баглс (Buggles) „Video Killed the Radio Star”, ангажован је за израду видео клипа Vienna. Марио Прац (Mario Praz) у својој студији Аїонја романйизма износи примере фаталних жена

$1 \quad$ Moj pol je zrak elektro tela, neonski obris na useljenom oblakoderu... koji baca senku na saobraćajne nesreće na vijaduktu. Ne nosi nikakva buduća lica i može biti sasvim slučajno muški ili ženski. (prev. aut.) 
оличених у литерарним моделима као што су Матилда, Кармен, Сесили и Кончита. То је тип жене, каже Прац, „који је у почетку шпански или креолски, на крају добија узор у женама Достојевског, међу којима је Настасја Филиповна најкарактеристичнија" (Прац 1974: 167). У Малкахијевом споту се између осталог први пут у музичкој индустрији појављује мотив европске фаталне жене. Чланови бенда су инкорпорирани у видео причу и помешани су са осталим статистима. Филмски критичар Петар Јончић у својој књизи о феномену музичких спотова који су снимани током осасмдесетих година двадесетог века под називом Музичке сликовнице осамgесейих примећује да су у музичком споту за песму Vienna лица чланова бенда: „нашминкана, озбиљна, кретање је минимално, једнолично, зомбијевски хладно.“ То је, каже даље: „била слика онога што се тада могло видети у лондонским клубовима, посебно у Rum Runner-у где је рођена мода Новог романтизма“" (Јончић 2015: 33).

Наш истакнути преводилац, књижевник и публициста Драгослав Андрић у својој чувеној антологији рок поезије

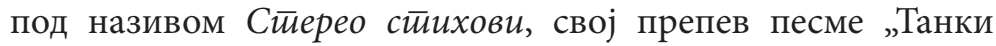
зид (The Thin Wall)“ групе Алтравокс који у рефрену носи својеврсну клетву у речима:

А онај што се руга, избледеће до смрти А онај што се смеје, саплешће се о стид А онај који зна, увек ће иза леђа Танак да осећа зид

смешта у поглавље које је по песми Sex Pistols-а назвао „Ја хоћу да будем ја“. Поред Алтравокса ту се налазе препеви група попут The Clash, The Stranglers и других. Један од последњих спотова које ће Малкахи режирати за Алтравокс биће управо видео за песму „The Thin Wall где ће користећи деконструкцију амбијента и кретање у нереалном простору прилично верно дочарати кошмар и тескобу наратора. Певач Миџ Јур пролази кроз ходнике из чијих зидова излазе руке које га додирују. Како Петар Јончић каже у поменутој књизи то је „прилично огољен цитат Коктоових филмских 
сновиђења“, међутим визуелно се постиже склад са музиком јер „електронски звук имагинацију чини снажнијом али никада не објашњава речи песме“. Другим речима, чланови бенда постају „мнемоничке слике“ (Јончић 2015: 37, 38).

Горе у тексту већ је поменут бирмингемски Rum Runner, један од многих клубова широм Енглеске који су били веома битни као окупљалиште нових романтичара. Музичкомодни састав Визаж (Visage) настао је на сличном месту у Лондону под називом Блиц (Blitz). Гости који су га посећивали, као и персонал, временом ће постати познати као Blitz Kids. Ty је као вратар клуба био запослен Стив Стрејнџ (Steve Strange, 1959-2015). Његово модно комбиновање футуристичких и ретро елемената, болеро шешира, златних трака, мушких свечаних појасева као и фризура у виду различитих геометријских облика, одредили су специфичан начин облачења који ће постати познат као Blitz Kids Style.

Музику је пуштао Расти Иган (Rusty Egan), бивши бубњар групе Рич кидс (Rich Kids), састава којег је основао Глен Метлок (Glen Metlock) по напуштању Секс пистолса. Интересантна је чињеница да је у истој групи гитару свирао већ помињани Миџ Јур. Била је то добитна комбинација; Стив Странге као певач, Расти Иган за бубњевима, Миџ Јур и Били Кари (Billy Currie), који ће се касниј прославити са Алтравоксом, и ништа мање него три музичара из групе Мегазин (Magazine): клавијатуриста Дејв Формјула (Dave Formula), гитариста Џон Мек Гоуч (John McGeoch) и басиста Бери Адамсон (Barry Adamson). Тако је Стрејнџ, како Сајмон Рејнолдс (Simon Reynolds) у својој обимној студији о постпанку у периоду 1978-1984 под називом Rip It up and Start Again каже: „постао лидер конфедерације пропалих панкера који су тражили другу шансу за пут до звезда.“ (Рејнолдс 2005: 326).

Први албум, који је носио назив као и са̂ма група Визаж, а појавио се у продаји крајем 1980. године, право је ремек дело електро-попа и његово појављивање на рафовима продавница плоча се може сматрати музичким уводом у период новог романтизма. Са албума се врло брзо издвојио сингл „Fade to Grey (Бледи до сивог)“, који је доспео на осмо место британских и на прво место немачких топ 
листа. Иновативни дизајн омота албума, на ком преовлађују индиго нијансе, резултат је заједничког труда свих чланова бенда и до дана данашњег дубоко је утиснут у сећања обожавалаца. Представља екстравагантно одевени плесни пар који је у заносу танго музике, док се иза њих виде силуете џез музичара са тромбоном, микрофоном и котрабасом. Текстом насловне нумере Visage позабавио се Драгослав Андрић, који у Сйерео сиичховима другу строфу песме: „Visuals, Magazines, Reflex styles, Past, future in extreme” луцидно претвара у четири стиха која се римују: “Штампа се критички Бави проблемима, Моје будућности Њеним екстремима” (Андрић 1983: 260). Видео спот за песму Блеgu gо сивої помало је наиван из данашње перспективе, међутим треба имати у виду да је то вероватно први спот у ком је тело једног певача, како Петар Јончић примећује, „ликовни простор на који се делује бојама“. „Исрцтавање доводи до метаморфозе“, каже у наставку Јончић a, „Стрејнџ се кроз крупни план приближава уметничком делу, постаје андроидска инсталација.“ (Јончић 2015: 122).

Из претходног се може видети како су се каријере два описана бенда међусобно испреплетале. Чланови групе Алтравокс - Миџ Јур и Били Кари значајно су учествовали у компоновању песама за Стрејнџов Визаж, који је остао у својој суштини студијски пројекат. Стив Стрејнџ је још неколико година на претходно утабаним стазама старе славе покушавао да одржи групу, али безуспешно. Међутим, одјеци песме Блеgи gо сивоі још увек не „бледе” нити „сиве”, а нове верзије и диско обраде се и данас могу чути по клубовима и дискотекама.

У носталгичном сећању људи који су своје детињство и тинејџерске дане осамдесетих година прошлог века проводили у држави која се звала Социјалистичка Федеративна Република Југославија (СФРЈ), веома често преовладава осећај да су то биле безбрижне године просперитета и економског напретка. Међутим, историјска је чињеница да то није било тако, како у Југославији тако ни у Европи и остатку света. Биле су то југословенске године економске стабилизације и многи савременици тог доба их памте по несташицама 
струје, бензина, кафе и детерџента. На глобалном нивоу, то је период: Фокландског рата, великог штрајка рудара у Британији, Ирачко-Иранског сукоба на Блиском истоку, и као што је у првом делу есеја поменуто, период владавине конзервативаца попут Маргарет Тачер и Роналда Регана. Поп култура и рок музика остали су без једног великана. Осмог деценбра 1980. године, испред зграде у којој је живео у Њујорку, убијен је Џон Ленон (John Lennon, 1940-1980). Стицајем околности тај бизарни догађај са трагичним сценаријом, на најгори могући начин, симболично ће најавити крај једне музичке ере и почетак једне сасвим другачије.

Социјалистичка Федеративна Република Југосла-вија је по много чему била специфична политичка творевина. Опште је позната историјска чињеница да је после сукоба југословенске КП са Информбироом 1948. године, промена политичког курса, када је совјетски тип социјализма представљен као насилни и израбљивачки, условила стварање позитивне слике наше земље на Западу. Међутим, без обзира на предстојеће деценије приближавања западној култури, популарна култура ће се до краја постојања СФРЈ ипак сматрати нижим обликом културе у односу на тзв. високу, елитну културу. Цитирајући бројне историчаре, а пре свега Предрага Марковића, Јелена Арнаутовић у својој студији о третману популарне културе на Радио Београду у СФРЈ под називом Између йолитиике и йржишйа истиче да се: „шездесетих година интензивирају процеси политичке либерализације, одступања од источног модела и укључивања у западноевропске токове у свим сферама“ (Арнаутовић 2012: 39). Експанзија универзитета као институције, гостовања бројних интелектуалаца из иностранства, оснивање музеја, покретање часописа, као и организовање разних изложби и фестивала, увели су државу у период такозваног „меког социјализма ", у коме је југословенска власт била толерантна према алтернативним облицима културног деловања. То је период покретања нових часописа попут Сусрети $а$ и Виgика у Београду и Полетиа у Загребу. Испоставиће се да ће они одиграти важну улогу улогу у попоуларизацији поп-рок музике на овим просторима. Полет̄ ће од друге половине 
седамдестих па све до средине осамдесетих година двадесетог века пропратити загребачки Нови вал пишући и извештавајући о раду и концертима група попут словеначких: Панкрта и Булдожера и хрватских: Азре, Прљавог казалишта, Филма, Хаустора и других. Суочиће се Полей и са повлачењем целог тиража и критиком власти када су 1980. године, након већ поменутог убиства Џона Ленона, објавили другу црно-белу насловницу.

Наиме, власти СФРЈ су критиковале тај чин јер се сматрало да се личност и дело Јосипа Броза Тита (неприкосновеног шефа државе, који је умро у мају исте године) не може упоређивати са Џоном Леноном. Сличан проблем ће се појавити у Новом Саду после 2000. године, када ће град једно кратко време имати улицу Џона Ленона. Индустрија плоча, развијена мрежа бројних радио станица које свој програм емитују на ултракратким (УКВ) таласима, као и појава телевизије 1958. године, неминовно су довели до ширења популарне музике на сваком кораку, а цена отварања земље, како Арнаутовићева цитира Мирославу Лукић-Крстановић, била jе: „увоз музичких трендова." (Арнаутовић 2012: 40). Овде је битно нагласити да је пасош постао доступан свима и грађани су без виза и нарочитих проблема могли путовати у све западноевропске земље. СФРЈ је да би смањила незапосленост и растеретила државни буџет склапала међународне уговоре са земљама које су примале радну снагу. Највише држављана Југославије одлазило је на рад у Западну Немачку (Савезна Република Немачка). Тај процес је имао такве размере да се у језику народа и народности одомаћила једна нова реч: Југошваба (гастарбајтер). На тај начин, брже су се пунили рафови са најновијим издањима плоча, касета и магнетофонских трака како приватних колекција тако и великих фонотека радио станица широм земље. Са таквом слободом кретања СФРЈ се видно одвојила од Истока и, како Арнаутовићева цитира Предрага Марковића: „позападњачила многе аспекте југословенске свакодневице." (Арнаутовић 2012: 40).

Осамдесетих година прошлога века у Југославији су функционисале бројне издавачке куће попут: РТЛ (Љубљана), 
Сузу (Загреб), Дискотон и Сарајево Диск (Сарајево), Југодиск (Београд), Хелидон (Љубљана). Издвојиле су се, међутим, две највеће: ПГП РТБ (Београд) и Југотон (Загреб). Прва се одликовала одмереном уређивачком политиком и високим тиражима углавном тражених издања. За њу су у то време издавали: Рибља Чорба, Балашевић, Леб и сол, Дадо Топић, Булевар, Галија, Пилоти, Слађана Милошевић, Генерација 5, Беби Дол и други. Потоња је по многима била најпрофесионалнија диско фирма у тадашњој Југославији. Под њеном етикетом издавали су: Бијело дугме, Азра, Идоли, Филм, Хаустор, Лабораторија, Драго Млинарец, Аеродром, Зана, Шарло акробата, Електрични оргазам и дуги. Храбра уређивачка политика Синише Шкарице промовисала је нови талас дуж осовине Ријека-Љубљана-Загреб-Београд. Интересантна је чињеница да су скоро сви нови београдски бендови потписали уговоре са загребачким Југотоном, а не београдским ПГП РТС-ом. Чувени Пакети аранжман, легендарна плоча која представља три београдска бенда: Шарла акробату, Електрични оргазам и Идоле као веснике Новог таласа, издао је управо Југотон 1981. године.

На насловној страни плоче налази се црно-бела фотографија Београда у магли. На симболичан начин на тој фотографији представљен је Београд у свом сивилу, а ништавило које се назире у позадини наговестило је наредну деценију. Сарадња и дружење новоталасних бендова из Загреба и Београда приказани су у филму Сретино gијейе режисера Игора Мирковића из 2003. године, који је добио име по истоименој песми Прљавог казалишта. Прва строфа ове песме гласи: „Ја сам одрастао уз ратне филмове у боји, уз честе тучњаве у школи, уз народне пјесме пуне боли." Године тзв. меког социјализма које су уследиле после Титове смрти поклапају се са периодом који обрађује овај рад. Савременици их памте по већ поменутим несташицама које су ипак остајале у сенци безбрижног младалаштва и бунтовног духа младе генерације која је наслућивала шта се дешава. Држава је практично у осамдесетим годинама почела да се дезинтегрише у свим сегментима: политичком, економском, друштвено-социјалном, па и националном. Били су то; за 
обичан свет невидљиви процеси. Велики дугови земље према иностранству условили су велику инфлацију, привредну рецесију и незапосленост. Председништво Југославије безуспешно се бавило економским питањима, тако да није имало времена да преко својих служби још додатно контролише и цензурише текстове младих новоталасних бендова. Тако су текстови попут „Сретног дјетета” Прљавог казалишта и „Маљчика” Идола уз додатне порезе могли да прођу све цензуре. Додатни порези су се наплаћивали када тзв. Комисија за шунд прогласи да одређена песма, књига, стрип или било који текст немају уметничку вредност, што је условљавало више цене дотичних производа. Не треба посебно наглашавати да је то била судбина многих поп-рок издања, укључујући и најновије новоталасне плоче и касете.

Међутим, чини се да нису сви аутори у потпуности схватали време у коме су стварали. Збуњеност и делимично неразумевање токова светске музике осамдесетих од стране појединих група које су тада стварале можемо најбоље представити прелиставајући поп-рок часописе, којих је тада било у изобиљу. Поменимо само: 82. У интервјуу са певачем загребачке групе Боа, Младеном Пуљизом, који је објављен у часопису Рок 82 од 28. 041982. године, на питање новинара Душана Весића у ком коментарише да му се чини, без обзира што их критика сврстава у нове романтичаре, да је симфо рок више утицао на њихову музику, Младен одговара: „На нас уопште није утицао Нови романтизам. Да се одмакнемо од тога, јер то не волимо. На нас су утицали рецимо David Bowie, Roxy Music, Talking Heads и наравно Ultravox." Младен Пуљиз је вероватно желео да се дистанцира од неких тинејџерских бендова тог доба попут Duran Duran, Culture Club, Kajagoogoo и других, међутим вероватно није био свестан да је набројао управо типичне представнике Новог романтизма који су наводно утицали на Боу. Дејвид Боуви, о којем је већ било речи у првом делу овог рада, својим спотом за песмом „Ashes to Ashes”, у ком се као статиста појављује већ поменути Стив Стрејн, поставио је темеље идеологије Новог романтизма, која се бави идентитетом, сексуалношћу и андрогинијом. Београдска група Дивљи 
анђели стекла је популарност почетком осамдесетих хит песмом „Воли те твоја звер”, без које се не може замислити ни једна ретро југоносталгичарска забава. Фронтмен групе Небојша Савић у интервјуу за часопис Рок 82 од 22. 09. 1982. године, на питање новинара Банета Обреновића каква су они група, одговара: „Имиџ нам је нека мешавина неоромантизма и надреализма, нешто између Боувија и неоромантичара, док нам је музика по некој нашој дефиницији рок отворених форми. Значи да у њој има и бита, и попа, и рока." У случају Дивљих анђела, очигледно је у питању злоупотреба новоромантичарског имиџа док текстови песама немају никакаве везе са, за оно време, актуелним темама којима се бавио Нови романтизам.

Џон Фиск (John Fisk) у својој књизи Пойуларна кул$\bar{u} y p a$, разликујући две врсте друштвених промена - радикалне и популарне, популарну културу види као процес трајних промена који је усмерен ка одржању или повећању силе одоздо. Он је, каже Фиск: „својствен људима унутар система. Резултира ублажавањем грубих крајњости моћи, производи мале добитке за себе, одржава њихово самопоштовање и идентитет. Прогресиван је, али не и радикалан” (Фиск 2001: 216). Такав процесс се, као одјек дешавања на Западу, могао запазити у социјалистичкој Југославији када је РТВ Београд почетком 1981. године ангажовала редитеља Станка Црнобрњу за покретање пројекта Беоіраg ноћу. Био је то провокативан шоу програм где је Оливер Мандић, обучен и нашминкан као жена, изазвао гнев бројних гледалаца, који су својим бесним писмима обасули редакцију телевизије Београд. Био је то пример како се сукобљавају конзервативни и нови ставови и како, по Фисковим речима: „ново знање није еволуционо побољшање онога што му претходи, него оно улази у непријатељске односе са старијим, утврђеним, доводећи у питање њихов положај у игри моћи различитих схватања, а таквим се сукобљавањем могу остварити нови увиди" (Фиск 2001: 223). Исте године је покренута телевизијска емисија; Хит месеца, која је у суштини била копија већ тада дугогодишње британске емисије под називом Тор of the Pops. У њој су се на тзв. плејбек (playback) појављивале 
звезде југословенског поп-рока представљајући, на тај начин, своје најновије нумере. Петар Јончић истиче да је та емисија била својеврсни прозор у туђе двориште, међутим, критикујући је на известан начин, ипак примећује да је: „Хит месеца сваком разумном гледаоцу показивао колико заостајемо за Малкахијем, Мелетом, Бероном или Грантом" (Јончић 2015: 214).

За сам крај можемо констатовати да су југословенски урбани центри попут Ријеке, Љубљане, Загреба, Сарајева, Новог Сада, Београда и Скопља оберучке пригрлили један нови, музички и модни вид популарне културе који се симултано појављивао на западном обзорју. Једини приговор који имамо ми, протагонисти тог времена, јесте да је период о ком говоримо кратко трајао. Новим генерацијама остаје да га истражују, размишљају о њему, одбаце све анахронизме и можда га инкорпорирају у неке нове вредности и значења.

\section{Извори и литература}

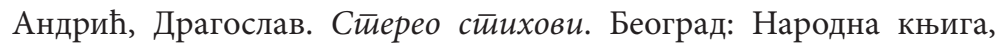
1983. Штампано.

Арнаутовић, Јелена. Између йолитиике и йржищйа. Београд: РТС, 2012. Штампано.

Балард, Џејмс Грејем. Чешивородимензионални кошмар, превео Новица Петровић. Београд: Фабрика књига, 2005. Штампано.

Јончић, Петар. Музичке сликовниие осамgесеиих. Београд: Службени гласник, 2015. Штампано.

Прац, Марио. Аїонија романтиизма, превела Цвијета Јакшић. Београд: Нолит, 1974. Штампано.

Reynolds, Simon. Rip It Up and Start Again. London: Faber abnd Faber Ltd, 2005. Штампано.

Фиск, Џон. Пойуларна кулимура, превео Зоран Пауновић. Београд: Клио, 2001. Штампано.

Heatley, Michael. The Deffinitive Illustrated Enciclopedia of Rock. London: Flame Tree Publishing, 2006. Штампано.

Clifford, Mike. New Ilustrated Rock Handbook. London: Salamander Books Ltd, 1988. Штампано. 


\title{
Jovan Savin
}

NEW ROMANTICS AS A PART OF BRITISH SOCIETY

IN THE FIRST YEARS OF THE $20^{\mathrm{TH}}$ CENTURY AND

JUGOSLAVIAN MUSICAL NEW WAVE AS AN ECHO OF

WESTERN POPULAR CULTURE ON THE BALKANS

\begin{abstract}
The paper represents an attempt at a sociological, economic, political and subcultural analysis of European and Yugoslavian societies in the 1980's from the perspective of pop music which is known as the New Romantic movement. Through the historical recollection of social events in Europe and Yugoslavia, the author analyzes the subcultural phenomenon of the music video as an innovation of Western civilization and the values which came with it, changing the political and artistic paradigm of Yugoslav society.
\end{abstract}

Key Words: New Romanticism, music video, Yugoslavian New Wave. 